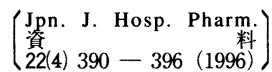

滅菌クロルヘキシジン製剂の開封後の安定性および効カ†

\author{
黒田今日子, 藤下 修, 小坪一哉, 中尾泰史 ${ }^{*}$, 大石了三 \\ 九州大学医学部附属病院薬骫部 $\dagger^{2}$
}

\title{
Stability and Potency of Sterilized Chlorhexidine Gluconate Solutions after Unsealing the Container ${ }^{1}$
}

\author{
KYOKO KURODA, OSAMU FUJISHITA, KAZUYA KOTSUBO, \\ YASUSHI NAKAO* and RYOZO OISHI \\ Department of Hospital Pharmacy, Faculty of Medicine, Kyushu University $\dagger^{2}$
}

\author{
$\left(\begin{array}{l}\text { Received November 20, } 1995 \\ \text { Accepted May 28, } 1996\end{array}\right)$
}

Sterilized chlorhexidine gluconate solutions $(\mathrm{GCH})$ in $500 \mathrm{ml}$ polypropylene containes are prepared in our hospital pharmacy. To determine the expiration period after unsealing the container, the stability and potency of $0.02 \% \mathrm{GCH}$ were examined by high-performance liquid chromatography and cultivation tests, respectively. The main ingredient of $0.02 \% \mathrm{GCH}$ which had been used partially for more than 6 months, was maintained at over $95 \%$ of its initial concentration at room temperature. No bacterium nor fungus was evident in the $0.02 \% \mathrm{GCH}$ partially used at several sections for $2-15$ months, when examined by three different cultivation tests. Under the conditions of excess microbe contamination such as falling microbial test and sticking fingers test, $0.02 \% \mathrm{GCH}$ prevented the growth of microbes. These results suggest that there is only a minor possibility of microbial contamination in the sterilized $0.02 \% \mathrm{GCH}$ after the container has been unsealed.

In general, this preparation may be usable for at least one month after unsealing although the existence of microbes resistant to GCH has been reported.

Key words - sterilized chlorhexidine gluconate solution, expiration period, microbe contamination, falling microbial test, sticking fingers test, stability

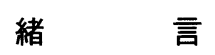

病院で用いられている消毒剤の多くは，長い間

$\dagger^{1}$ 本論文は第 5 回日本病院薬学会年会（東京, 1995年 7 月）で発表.

$\dagger^{2}$ 福岡市東区馬出 3-1-1；3-1-1, Maidashi, Higashi-ku, Fukuoka, 812-82 Japan
病院薬剂部で滅菌され供給されてきたが, 滅菌消 毒剂の有用性が広く認められてくるとともに多く の市販品が見られるようになった。そそのうち，滅 菌した市販のグルコン酸クロルヘキシジン液（以 下 $\mathrm{GCH})$ の添付文書には『開封後は直ちに使用 し，一部を使用した残液は再使用しないこと $\mathfrak{d}^{1)}$, あるいは『中栓を取り除いた場合には, 改めて滅 
菌すること】2) などと記載されている。しかし， これらの滅菌消毒剤の開封後の安定性および効力 の持続についは，臨床上重要であるにもかかわら ず，それらに関するデータは見当たらない．そこ で, 当院薬郕部で調製し, 滅菌している $500 \mathrm{ml}$ ポ リプロピレン製容器入り $0.02 \% \mathrm{GCH}$ について, 開封後の使用期限の設定を目的として，その安定 性および効力について検討した.

\section{実 験 の 部}

1. 高速液体クロマトグラフィー（HPLC）法に よる安定性の検討

\section{1 ) 試料および試薬}

当院薬剂部では, $20 \% \mathrm{GCH}$ (ゼネカ(侏) $100 \mathrm{ml}$ を蒸留水 $100 \mathrm{~L}$ で希䣋し $500 \mathrm{ml}$ ポリプロピレン製 容器に充填後, $110^{\circ} \mathrm{C} 40$ 分間高圧蒸気滅菌を行い, 1 回の操作により滅菌0.02\% GCH500ml を200本 調製している。上記のように調製したもののうち 薬剤部で使いかけのもの（室温保存）を回収し試 料とした。

過塩素酸ナトリウム一水和物, リン酸, アセ卜 ニトリル，パラクロロアニリン（いずれも和光純 薬(侏)，リン酸二水素ナトリウム二水和物（半井 化学(侏) はいずれも特級以上のものを用いた。

\section{2 ）装置および条件}

a ) 装置

ポンプ： LKB BROMMA 2150 HPLC PUMP, 検 出 器: Shimadzu SPD-2A SPECTRO PHOTOMETRIC DETECTOR, データ処理装置：TOYO SODA CHROMATO PROCESSOR CP-800をそれぞれ用 いた.

\section{b ）条件 ${ }^{3)}$}

カラム : TSKgel ODS-120T, 移動相 : 0.1M 過 塩素酸ナトリウム $-0.01 \mathrm{M}$ リン酸緩衝液:アセト ニトリル混液 $(55: 45, \mathrm{v} / \mathrm{v})$, 流速 $: 1.0 \mathrm{ml} / \mathrm{min}$, 検出波長：197nm の条件下で測定した.

\section{2. 培養法による効力の検討}

\section{1) 試料}

上記のように調製した滅菌0.02\%GCH のう
ち, 病棟で使いかけのもの（室温保存）を回収 し，下記の方法(1)〜(3)についてはこれを試料とし た. 方法(4)よび5については滅菌後未開封のも のを試料とした.

\section{2 ) 培地}

チオグリコール酸培地（以下 TG）, ブドウ糖 ペプトン培地 (以下 GP), ブレインハートイン フュジョン寒天培地 (以下 BHIA), ハートイン フュジョン寒天培地（以下 HIA）, チオグリコー ル酸培地（いずれも栄研化学(株) に $1.5 \%$ 割合 で寒天（和光純薬(株) を加えたもの（以下 TGA), ブドウ糖ペプトン培地に1.5\%の割合で 寒天を加えたもの（以下 GPA）を用いた。

\section{3）方法}

(1)直接法

$\mathrm{GCH}$ を含んだままの試料約 $1 \mathrm{ml}$ を培地に添加 して培養した。

(2)中和法 ${ }^{4,5)}$

$\mathrm{GCH}$ の影響を除去するために，試料 $0.5 \mathrm{ml} に$ ヒビテン中和剤 (住友製薬(侏) $0.5 \mathrm{ml}$ を加え培地 に添加して培養した。

(3)メンブランフィルター法6)

GCH の影響を完全に除去するために，病棟か

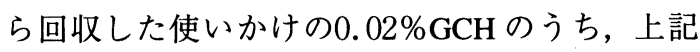
の直接法および中和法で用いた数 $\mathrm{ml}$ の試料を除 くすべての試料（約 $100-400 \mathrm{ml}$ ) を孔径 $0.22 \mu \mathrm{m}$ のメンブランフィルター (ミリポア(株) でろ過を 行い, $0.1 \%$ 滅菌ポリペプトン (和光純薬(侏) 水 100 $\mathrm{ml}$ で 3 回洗浄した後，そのフィルターを 2 分割 し TG および GPに入れ培養した。

(4)落下菌試験法

a ) $0.02 \% \mathrm{GCH}$ 容器を開放した落下菌試験： 滅菌0.02\%GCH 容器のふたを24時間開放した 後, その中の $\mathrm{GCH} 1 \mathrm{ml}$ を試料として培地に添加 して培養した.

b ） $0.02 \% \mathrm{GCH}$ を表面塗布または混和した培 地による落下菌試験：0.02\% GCH 約 $1 \mathrm{ml}$ を表面 塗布，または培地作製に $0.02 \% \mathrm{GCH}$ を用いてあ らかじめ培地全体に GCH を混和した固形培地を 
1 時間開放して落下菌試験を行った。

c）試料開放場所：試料の開放は, 製剤管理室 (面積: $55 \mathrm{~m}^{2}$, 人員 : 2 名), 調剤室(面積: 264 $\mathrm{m}^{2}$,人員: 19 名）および分室（面積: $104 \mathrm{~m}^{2}$, 人員：7名）で行った。なお，いずれも病棟と同 様の空調設備である.

Table 1．HPLC 法による0.02\%グルコン酸 クロルヘキシジン開封後の安定性

\begin{tabular}{c|c}
\hline 調製後の期間 & 主成分 $(\%)$ \\
\hline 1 カ月 & $97.2 \pm 0.5$ \\
3 カ月 & $99.7 \pm 0.8$ \\
6 カ月 & $96.4 \pm 1.2$ \\
\hline \multicolumn{2}{|c}{$($ mean \pm S.D., $\mathrm{n}=3)$}
\end{tabular}

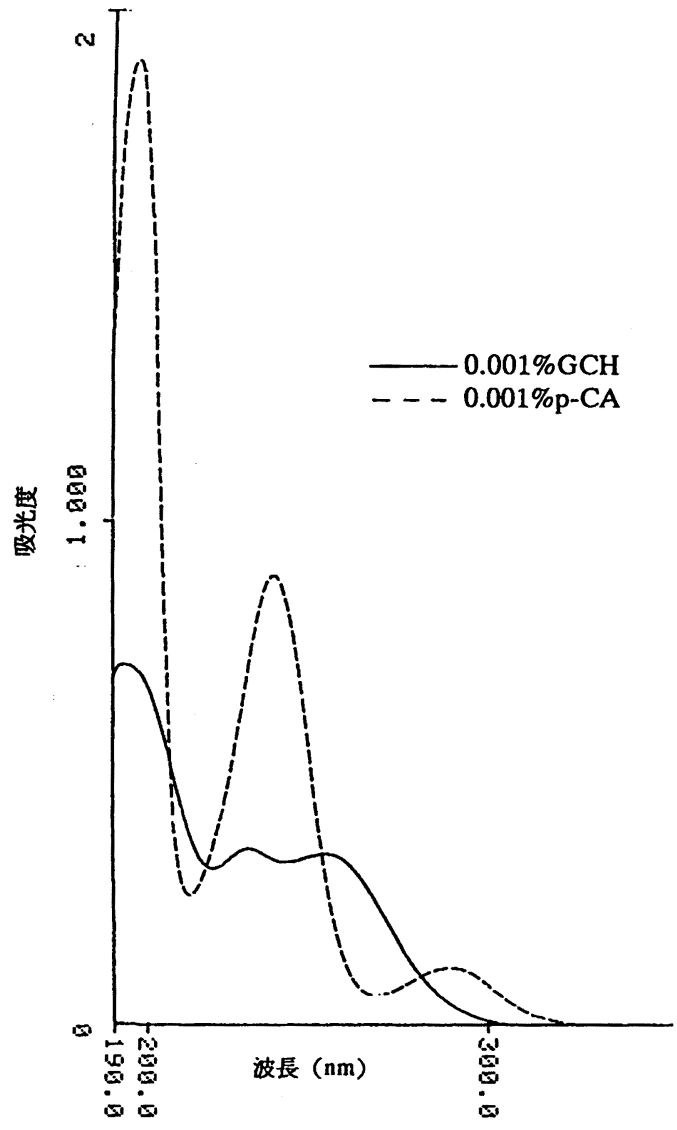

Fig. 1.0.001\%グルコン酸クロルヘキシジン (GCH）および0.001\%パラクロロアニ リン（p-CA）の吸収ピーク

\section{(5)手指付着菌試験法}

a ) $0.02 \% \mathrm{GCH}$ に指を直接接触させた手指付 着菌試験：0.02\%GCH $500 \mathrm{ml}$ 容器に人差し指を入 れ，中の $\mathrm{GCH}$ に第一関節までを $1-5$ 回接触さ

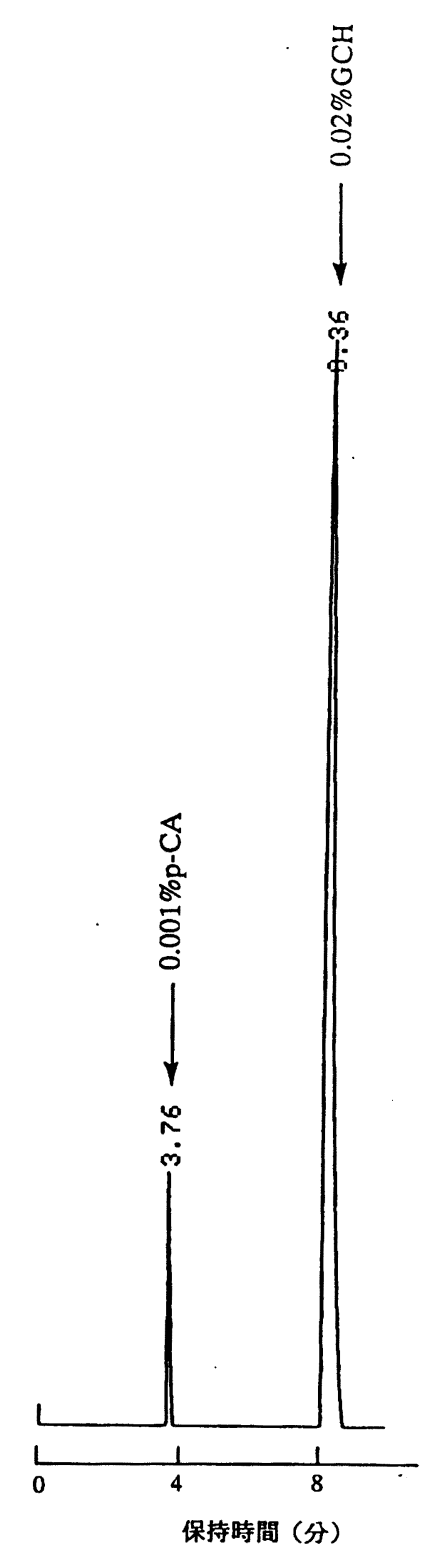

Fig. 2.0.02\%グルコン酸クロル ヘキシジン $(\mathrm{GCH})$ およ び0.001\%パラクロロアニ リン（p-CA）の HPLCク ロマトグラム 
せ，その液 $1 \mathrm{ml}$ を試料として培地に添加して培 養した。

b ） $0.02 \%$ GCH を表面塗布または混和した培 地による手指付着菌試験：(4)のb）と同様に作製 した培地に，人差し指，中指，薬指の 2 本の第一 関節の内側を接触させ培養した。

\section{結果および考察}

\section{HPLC 法による安定性の検討}

ポリプロピレン製容器入り $0.02 \% \mathrm{GCH}$ は開封 後も, 室温保存で主成分は 3 試料とも 96-99\%強 の割合で検出された (Table 1$)$.なお調製した0.02 GCH で高圧蒸気滅菌前のものを $100 \%$ とした. GCH の主な分解物であるパラクロロアニリン

（以下 p-CA）は波長 $197 \mathrm{~nm}$ 付近に吸収極大を示 し,この吸光度は同濃度の $\mathrm{GCH}$ の約 2 倍である (Fig. 1 )。 また, 分解物 p-CA が GCH 濃度の 5 \%と仮定した場合のクロマトグラムを Fig. 2 に 示す. 滅菌前, 滅菌後および開封約半年後の試料 いずれにも p-CA に該当するピークは見られなか った。この結果は, $\mathrm{GCH}$ 滅菌後の p-CA 濃度が わずか $0.3 \%$ あるるとする GOODALL ら ${ }^{7)}$ と一致 する. また, 調製後 1 力月と 3 力月の主成分の值 が逆転しているが，製造ロット間の調製誤差や， 開封の回数あるいは残存量の差などの使用条件の
違いが影響していると思われる。

\section{2. 培養法による効力の検討}

1 ）直接法による0.02\%GCH 開封後の効力試 験

調製後 2 〜 カ月を経た試料のいずれにも菌の 発育は見られなかった。

2 ）中和法による0.02\%GCH 開封後の効力試 験

中和法で GCH の影響を除去して培養した場合 でも, 調製後 2 カ月〜 1 年 3 力月を経た試料のい ずれにも菌の発育は見られなかった（Table 2$).$

3 ）メンブランフィルター法による0.02\%

\section{GCH 開封後の効力試験}

メンブランフィルター法で残りすべての $\mathrm{GCH}$ をろ過し，その影響を完全に除去した場合でも菌 の発育は見られなかった（Table 3)，GCH の影 響を除去した中和法およびメンブランフィルター 法によるこれらの結果から, 滅菌 $0.02 \% G C H を$ 開封し使用中に容器内に微生物が混入したとして も，十分な作用時間のために容器内で微生物は死 滅すると考えられる。このことは $\mathrm{GCH}$ 濃度と作 用時間との関係について述べられた報告 ${ }^{8-10)} に よ$ っても推察される.

\section{4 ) 落下菌試験法}

(1) $0.02 \% \mathrm{GCH}$ 容器を開放した落下菌試験

Table 2 . 中和法による0.02\%グルコン酸クロルヘキシジン開封後 の効力試験

\begin{tabular}{|c|c|c|c|c|c|}
\hline 使用場所 & 調製後の期間 & TG & GP & TGA & GPA \\
\hline 耳 鼻 科 & 力 & - & - & - & - \\
\hline 循環器内科 & 月 & - & - & - & - \\
\hline 小 巟 科 & 力 月 & - & - & - & - \\
\hline 婦 人 科 & 力 月 & - & - & - & - \\
\hline 小児外科 & 力 & - & - & - & - \\
\hline 泌尿器科 & 力 月 & - & - & - & - \\
\hline 内 科 & カ & - & - & - & - \\
\hline 心臓外科 & カ & - & - & - & - \\
\hline 放射 線 科 & 1 年 3 力月 & - & - & - & - \\
\hline
\end{tabular}

一：菌の発育なし, 試料 : $0.5 \mathrm{ml}$, 中和剤 : $0.5 \mathrm{ml}$.

$\mathrm{TG}$ ：チオグリコール酸培地, GP：ブドウ糖ペプトン培地, TGA：

チオグリコール酸寒天培地, GPA：ブドウ糖ペプトン寒天培地 
Table 3 . メンブランフィルター法による0.02\%グルコ ン酸クロルヘキシジン開封後の効力試験

\begin{tabular}{|c|c|c|c|}
\hline 使 用 場 所 & 調製後の期間 & TG & GP \\
\hline 循環器内科 & カ & - & - \\
\hline 小 児 科 & 力 月 & - & - \\
\hline 婦 人 科 & 力 月 & - & - \\
\hline 小児外科 & 3 力 月 & - & - \\
\hline 泌尿器科 & 5 力 月 & - & - \\
\hline 内 科 & 6 力 月 & - & - \\
\hline 放射 線 科 & 1 年 3 力月 & - & - \\
\hline
\end{tabular}

一: 菌の発育なし.

試料：(約100-400ml)をろ過したフィルターを培養.

$\mathrm{TG}$ ：チオグリコール酸培地, GP：ブドウ糖ペプトン培地.

滅菌消毒剂の開封後污染の主な原因の一つは, 使用時に容器の開口部より落下菌が混入すること である．実際の小分けによる使用時の開放時間は 容器のふたをあけて他の容器に移すまでの時間で あるから，長くても 1 回に30秒程度であると考え られる. $500 \mathrm{ml}$ の場合, $10 \mathrm{ml}$ ずつ50回に分けて 使用したとしても開放時間の累計は 1500 秒，すな わち25分程度である．著者らは苛酷試験の一つと して，その約50倍以上の時間である24時間, 滅菌 $0.02 \% \mathrm{GCH}$ の容器を製剂管理室, 調剤室および 分室（病棟部門の調剤室）で開放してその試料を 直接培養したが，いずれにも菌の発育は見られな かった (Table 4 ).

(2) $0.02 \% \mathrm{GCH}$ を表面塗布または混和した培地 による落下菌試験

著者らは更に苛酷試験の一つとして，0.02\%
GCH を表面塗布または混和させた固形培地のシ ヤーレを，製剤管理室，調剤室および分室（病棟 部門の調剤室）で 1 時間開放して落下菌試験を行 った. $500 \mathrm{ml}$ 容器開口部の直径は $18 \mathrm{~mm}$ と狭く, 例え長時間（24時間）ふたを開放しても微生物が 落下し混入する確率は低いと考えたからである. シャーレの直径は $90 \mathrm{~mm}$ であるので，開放面積は ポリ容器の約25倍である。しかし，この場合のい ずれにも菌の発育は見られなかった。なお，ブラ ンクとして $0.02 \% \mathrm{GCH}$ を含まない培地を 1 時間 開放した落下菌試験では，29-47個のコロニーを 確認した。これらの結果から, 滅菌 $0.02 \% \mathrm{GCH}$ 使用時に微生物が落下混入しても増殖は抑制さ れ，十分な静菌作用を示すと考えられる。

\section{5 ）手指付着菌試験法}

(1) $0.02 \% \mathrm{GCH}$ に指を直接接触させた手指付着 菌試験

滅菌消毒剤の開封後污染のもう一つの主な原因 は, 使用時に容器の開口部に手指が接触し手指に 付着している微生物が混入することである．実際 の小分けによる使用時には，よほど不注意な取り 扱いをしない限り直径 $18 \mathrm{~mm}$ の容器の開口部に指 を入れることはあり得ず，せいぜい開口部の端に 手指が接触する程度であると思われる，そこで著 者らは苛酷試験の一つとして, 容器内の $0.02 \%$ $\mathrm{GCH}$ に指を接触させそれを試料として培養した が，いずれも菌の発育は見られなかった.

(2) $0.02 \% G C H$ を表面塗布または混和した培地

Table 4.0.02\%グルコン酸クロルヘキシジンを表面塗布または混和した培地による落下菌試験

\begin{tabular}{|c|c|c|c|c|c|c|c|}
\hline \multirow{2}{*}{$\begin{array}{c}\text { 開 放 時 間 } \\
\text { (時間) }\end{array}$} & \multirow{2}{*}{ 開 放 場 所 } & \multicolumn{2}{|c|}{ BHIA } & \multicolumn{2}{|c|}{ HIA } & \multicolumn{2}{|c|}{ GPA } \\
\hline & & 塗布 1$)$ & 混和 ${ }^{2)}$ & 塗布1) & 混和 ${ }^{2)}$ & 塗布 ${ }^{1)}$ & 混和 ${ }^{2)}$ \\
\hline 1 & 調 剂 室 & - & - & - & - & - & - \\
\hline 1 & 製剂管理室 & - & - & - & - & - & - \\
\hline 1 & 分 室 & - & - & - & - & - & - \\
\hline
\end{tabular}

一: 菌の発育なし.

*0.02\% GCH 無添加培地で 1 時間開放した場合.コロニー数は29-47個であった.

1）培地の表面に0.02\%GCH を塗布したもの，2）培地全体に0.02\%GCH を混和したもの.

分室：病棟部門の調剤室, BHIA：ブレインハートインフュジョン寒天培地, HIA：ハートインフュジョン 寒天培地, GPA：ブドウ糖ペプトン寒天培地 


\section{による手指付着菌試験}

著者らはもう一つの苛酷試験として， $0.02 \%$ $\mathrm{GCH}$ を表面塗布または混和させたシャーレ上の 固形培地に手指を直接接触させて培養した. $\mathrm{GCH}$ を表面塗布した培地の中に 1 個と 3 個のコ ロニーの発育がみられたものがあった．同定を試 みたところ表皮ブドウ球菌と系状菌と思われるも のであった。これらの菌の MIC は $0.02 \%$ 以下で ある11)ことが知られていることから，コロニー の発育がみられたことについては $0.02 \% \mathrm{GCH}$ が 抗菌力を示す菌量以上の菌が被験者の手指に付着 していたこと，あるいは培地に表面塗布した GCH 量が少なかったために手指を接触させた際 に接触部の培地の $\mathrm{GCH}$ 量が減少してコロニーが 発育した可能性などが考えられる。

一方，あらかじめ $0.02 \% \mathrm{GCH}$ を混和した培地 ではいずれにも菌の発育は見られなかった。な お，ブランクとして $0.02 \% \mathrm{GCH}$ を含まない培地 で手指付着菌試験を行ったところ，2 個から密集 による計数不能までコロニーの数に幅が見られた

Table 5.0.02\%グルコン酸クロヘキシジンを表面塗布 または混和した培地による手指付着菌試験

\begin{tabular}{|c|c|c|c|c|c|c|}
\hline \multirow{2}{*}{$\begin{array}{l}\text { 被 } \\
\text { 験 } \\
\text { 者 }\end{array}$} & \multicolumn{2}{|c|}{ BHIA } & \multicolumn{2}{|c|}{ HIA } & \multicolumn{2}{|c|}{ GPA } \\
\hline & 表面1) & 混和 ${ }^{2)}$ & 表面1) & 混和 ${ }^{2)}$ & 表面1) & 混和 ${ }^{2)}$ \\
\hline a & - & & - & & $+(3)$ & \\
\hline b & - & & - & & $+(1)$ & \\
\hline c & - & & - & & - & \\
\hline $\mathrm{d}$ & - & & - & & - & \\
\hline $\mathrm{e}$ & - & & - & & - & \\
\hline $\mathrm{f}$ & & - & & - & & - \\
\hline $\mathrm{g}$ & & - & & - & & - \\
\hline $\mathrm{h}$ & & - & & - & & - \\
\hline $\mathrm{i}$ & & - & & - & & - \\
\hline
\end{tabular}

一: 菌の発育なし. + : 菌の発育あり; ( )内はコロニー数, $* 0.02 \% \mathrm{GCH}$ 無添加培地で付着菌試験を行った場合, コロニー数は 2 個から密集による計数不能まで幅があっ た. 1 ）培地の表面に $0.02 \% \mathrm{GCH}$ を塗布したもの, 2 ）培地全体に $0.02 \% \mathrm{GCH}$ を混和したもの.

BHIA：ブレインハートインフュジョン寒天培地, HIA： ハートインフュジョン寒天培地, GPA：ブドウ糖ペプト ン寒天培地.

\section{(Table 5 ).}

これらの結果から, 滅菌0.02\%GCH 使用時に 容器の開口部に手指が接触し, わずかに手指付着 菌が混入しても増殖は抑制され，十分な静菌作用 を示すと考えられる.

培地には様々な用途のものがあるが, 日本薬局 方収載のメンブランフィルター法においては規定 の液体培地 ${ }^{6)}$ を用い, 中和法においてはこれに 加えて液体培地での判定をコロニーによる確認で 容易にするため, 液体培地に寒天を加え固形培地 としたもの年も用いた。また他の方法では，栄 養要求の厳しい菌の生育に適しており広く用いら れいる12) 培地も用いた。このように, 病棟から 回収した使いかけの $\mathrm{GCH}$ に混入する可能性のあ る多種類にわたる菌の発育に適するように，それ ぞれ特性のある培地を数種類用いた.

GCHの添付文書には『Alcaligenes, Pseudomonas, Achromobacter, Flavobacterium 属等には, まれに GCH に抵抗する菌株もある】13) との記載 がある。これらの引用文献のうち, Alcaligenes faecalis の一部の株にBHIA 培地では最小発育阻 止濃度（MIC）が0.02-0.05\%, BHI broth 培地で は最小殺菌濃度（MBC）が $0.0125 \%$ ものがあ る ${ }^{14)}$ との報告があるが, 同一菌株で MIC に0.02$0.05 \%$ と幅があること, また培地が若干異なるも のの MBCより MICが大きいことにもやや疑問 が残る.また，いくつかの菌種について GCH の MIC に関する報告があるが15)，0.02\%を上回って いるのはわずかに Flavobacterium meningosepticum の中の一株のみである. Pseudomonas cepacia, Achromobacter xylosoxidans の一部は常用濃度で死 滅しないとの報告があるが16)，接種菌量が $10^{8} /$ $\mathrm{ml}$ であり，この菌量は滅菌 GCH 開封後に混入す る可能性のある菌量としてははるかに多い量であ る.

他にも, Candida albicans, Staphylococcus aureus などの一部の株を $0.02 \% \mathrm{GCH}$ と15-60分間作用さ せた場合, 殺菌されなかったという報告がある が10，17)，作用時間を30分-24時間としたものでは 


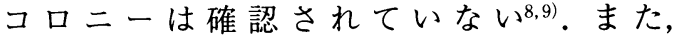
Pseudomonas cepacia の GCH 抵抗菌に関する別の 報告 ${ }^{18)}$ もあるが, それは接種菌量が $10^{7}-10^{10} / \mathrm{ml}$ と 多く，他にこの菌の MIC は0.0156\%以下である との報告 ${ }^{19)}$ もある。 $0.02 \% \mathrm{GCH}$ 中に Alcaligenes faecalis が認められたという報告 ${ }^{20)}$ があるが，未 滅菌製剤のものである。また，検出された30件は 同一菌種であり，1-2 個 $/ \mathrm{ml}$ のみののが10件 もあることから, GCH 内で増殖は抑制され，静 菌状態を示していると考えられる。

以上のことを総合的に考察すると, 実験結果か ら滅菌 GCH 開封後に微生物污染の起きる可能性 は低いと考えられ，また污染が起きたとしても， 文献的には通常の小分けによる使用方法での污染 菌量では，GCH 容器内で静菌状態が保たれてい ると考えられる。

本研究は冒頭で述べたように, 滅菌 GCH 開封 後の使用期限の設定を目的として行ったものであ る. 著者らの実験結果では, 数力月間の使用の可 能性を示唆している. しかし, 文献上の抵抗菌に よる污染の可能性とその危険性も考慮する必要が ある。したがって, 最終的には個々の使用環境と 使用目的等によって判断せざるを得ないが，通常 の小分けによる使用方法では開封後, 室温保存で 1 力月程度は問題ないと思われる.

\section{引用文 献}

$1 ） 0.05 \%$ ヘギック水添付文書, 吉田製薬株式会 社 (1994).

2 ） $0.05 \%$ マスキン水添付文書, 丸石製薬株式会社 (1995).

3 ）健栄製薬株式会社社内資料.
4 ) 横手千秋, 住田薫, 船岡恒陽, 医薬ジャーナ ル, 20, 691-694 (1984).

5 ) 吉原なみ子, 東海林寿子, 飯島肇, 浦田和樹, 臨床病理，36，842-846 (1988)。

6 ）日本公定書協会監修, “第十二改正日本薬局方解 説書”，廣川書店，東京, 1991, B-391-397.

7 ) R. R. GOODALL, J. GOLDMAN and J. WOODS, Pharm J, 200, 33-34 (1986).

8 ) 小池早苗, 小泉美智子, 宮脇真弓, 佐藤薰, 原 一寿, 中平法子, 高野みどり, 山田喜紹, 看護 技術，33，1069-1074（1987）.

9 ) 岩田寿男, 安江慶二, 網岡克雄, 水野宗道, 伊 藤一弘，小菅邦義，薬局，44，187-191（1993）.

10）森下憲一, 榊原雅代, 竹内美恵子, 原久美子, 稲生泰子, 杉江紀信, 重田勝美, 大橋昭任, 榊 原文孝，医療ジャーナル，20，97-107（1984）。

11）高杉益充編, “改訂版 消毒剂”, 医療ジャーナ ル社, 東京, 1990, pp. 228-229.

12）三瀬勝利, 川村邦夫, 石関忠一編, “GMP 微生物 試験法”, 講談社, 東京, 1993, pp.219, pp.391.

13）ヒビテン・グルコネート液添付文書, ゼネカ株 式会社（1993）.

14）金㑆貞, 近野聖子, 感染症学雑誌, 52, 10-15 (1978).

15）西岡きよ, 荒井澄夫, 本田一陽, 滝島任, 臨床 病理, 26, 721-725 (1977).

16）全田浩, 太田伸, 臨床泌尿器, 35, 627-636 (1981).

17) 大月千祐, 佐藤玲子, 勝野陽子, 竹中千里, 早 田道治, 吉村正一郎, 医薬ジャーナル, 20, 12971304 (1984).

18）小林順子, 柳沢節子, 松田佳苗, 中平法子, 清 水妙子, 鈴木順子, 近藤千枝子, 山田喜紹, 看 護技術，28，2071-2077（1982）。

19）西山泰暢, 小山真理子, 伊藤満子, 臨床病理, 25, 209-216 (1977).

20）風間殸, 黒田健, 九州薬学会会報, $23-26 ； 27-$ 30 (1976). 